九州大学学術情報リポジトリ

Kyushu University Institutional Repository

\title{
Topological Design of Star Glycopolymers for Controlling the Interaction with the Influenza Virus
}

Nagao, Masanori

Department of Chemical Systems and Engineering, Kyushu University

Matsubara, Teruhiko

Department of Biosciences and Informatics, Keio University

Hoshino, Yu

Department of Chemical Systems and Engineering, Kyushu University

Sato, Toshinori

Department of Biosciences and Informatics, Keio University

他

ht tp://hdl. hand le. net/2324/2320611

出版情報：Bioconjugate Chemistry. 30 (4)，pp.1192-1198，2019-05-12. American Chemical Society バージョン：

権利関係 : ๑ 2019 American Chemical Society 


\section{Topological Design of Star Glycopolymers for Controlling the}

\section{Interaction with the Influenza Virus}

Masanori Nagao ${ }^{1}$, Teruhiko Matsubara ${ }^{2}$, Yu Hoshino ${ }^{1}$, Toshinori Sato ${ }^{2}$, and Yoshiko Miura ${ }^{1 *}$

${ }^{1}$ Department of Chemical Engineering, Kyushu University, 744 Motooka Nishi-ku, Fukuoka 819-0395, Japan

${ }^{2}$ Department of Biosciences and Informatics, Keio University, 3-14-1 Hiyoshi, Kohoku-ku, Yokohama, Kanagawa 223-8522, Japan

Email: miuray@chem-eng.kyushu-u.ac.jp

KEYWORDS: Star polymer, reversible addition-fragmentation chain transfer (RAFT) polymerization, influenza virus, glycopolymer, multivalent interaction

\section{ABSTRACT}

The precise design of synthetic polymer ligands using controlled polymerization techniques provides advantage for the field of nanoscience. We report the topological design of glyco-ligands based on synthetic polymers for targeting hemagglutinin (HA, lectin on the influenza virus). To achieve precise arrangement of the glycounits toward the sugar-binding pockets of HA, triarm star glycopolymers were synthesized. The interaction of the star glycopolymers with HA was found to depend on the length of the polymer arms, and was maximized when the hydrodynamic diameter of the star glycopolymer was 
comparable to the distance between the sugar-binding pockets of HA. Following the formula of multivalent interaction, the number of binding sites in the interaction of the glycopolymers with HA was estimated as $1.8 \sim 2.7$. Considering one HA molecule has three sugar-binding pockets, these values were reasonable. The binding mode of synthetic glycopolymer-ligands toward lectins could be tuned using controlled radical polymerization techniques. 


\section{Introduction}

Building well-defined nanostructures is a fundamental goal in nanotechnology. Synthetic polymers in nanoscience present many advantages for the development of new materials. ${ }^{1}$ To push up the precision level of the structure of the synthetic polymers to be comparable to that of natural biopolymers such as DNA and peptides, controlled polymerization techniques have been developed that allow the structures of synthetic polymers—-molecular weight and monomer sequence — to be well defined. ${ }^{1-3}$ Controlled radical polymerization (CRP) is a particularly promising method for preparing wellcontrolled polymers, as a wide range of monomers and solvents can be used., ${ }^{4,5}$

One application for controlled bottom-up nanotechnology is the synthesis of biological ligands. In nature, biological ligands exhibit multivalent interactions with target molecules. ${ }^{6-8}$ The carbohydrate-protein interaction is an example of a multivalent interaction in body, and is involved with physiological phenomena such as pathogen infection. ${ }^{6-8}$ Glycoconjugates on the cell surface bind to multiple sugar-binding pockets on the corresponding protein (lectin) surface, where the cumulative effect of weak monovalent binding leads to a strong interaction (cluster glycoside effect). ${ }^{9}$ To achieve the cluster glycoside effect, the spatial arrangement of the glycounits must be considered when designing the glyco-ligands. An optimized ligand structure that has the precise glycounit arrangement toward the sugar-binding pockets of the lectin will exhibit a strong interaction, ${ }^{10,11}$ leading to the development of nano-medicines against pathogens.

The well-defined structures of DNA and peptides enable topological design of ligand structures 
(e.g., branched, cyclic, and further three-dimensional structures). ${ }^{12-15}$ This property is important for controlling the spatial arrangement of glycounits because the sugar-binding pockets of some lectins are placed radially on their surface. For example, influenza virus, which is an important target in bioscience owing to the threat of pandemic, has the lectin hemagglutinin (HA) on the surface. HA has a homo trimeric structure, and each subunit has one sugar-binding pocket. ${ }^{16,17}$ The three binding pockets exist on the vertices of the triangle shape on the HA surface, and the virus binds to sialyloligosaccharides on the cell surface through the multivalent interaction. ${ }^{16,17}$ Recent studies, aiming to develop effective virus inhibitors, reported trimeric glyco-ligands based on DNA and peptides with radial structures, which fit into the arrangement of the three binding pockets of HA. ${ }^{18-20}$ However, most of the synthetic polymer ligands with glycounits (glycopolymers) targeting HA had linear structures, ${ }^{21-}$ 24 and there have been no reports of the topological design of glycopolymers engineered to have precise glycounit arrangement toward the sugar-binding pockets of HA.

This work describes the topological design of synthetic polymer ligands for HA using CRP. To control the spatial arrangement of glycounits toward the binding pockets of HA, glycopolymers with star structures (star glycopolymers) were synthesized (Figure 1a, b). The star glycopolymers were designed to be a tri-arm structure to allow for multiple binding to the three sugar-binding pockets of HA. The influence of structures of the star glycopolymers on the interaction with HA was evaluated by a hemagglutination inhibition assay. 


\section{Results and Discussion}

Synthesis of star glycopolymers functionalized with 6'-sialyllactose.

The triarm star glycopolymers were prepared by reversible addition-fragmentation chain transfer

(RAFT) polymerization with the trifunctional RAFT agent. In the polymerization procedure, core-first approach was adopted to guarantee the homogeneity of the number of the polymer arms for the star polymer molecules. ${ }^{25}$ Each polymer arm was composed of two block segments: an inert spacer segment and a glycounit segment. First, the inert block segment was prepared by polymerization of $N, N$-dimethylacrylamide (DMA) in $N, N$-dimethylformamide (DMF). Three star DMA polymers with different length polymer arms were synthesized, and the target degree of polymerization (DP) was set at 30,50 , and 100 . The conversion rates of these polymers were 80,86 , and $87 \%$, respectively ( $\mathbf{S D}_{24}$, $\mathbf{S D}_{46}$, and $\mathbf{S D}_{95}$ in Table 1). The polymerization kinetics of $\mathbf{S D}_{\mathbf{4 6}}$ was studied in detail. The plots of $[\mathrm{M}]_{0} /[\mathrm{M}]$ to reaction time and the plots of molecular weight to conversion rate showed the linear

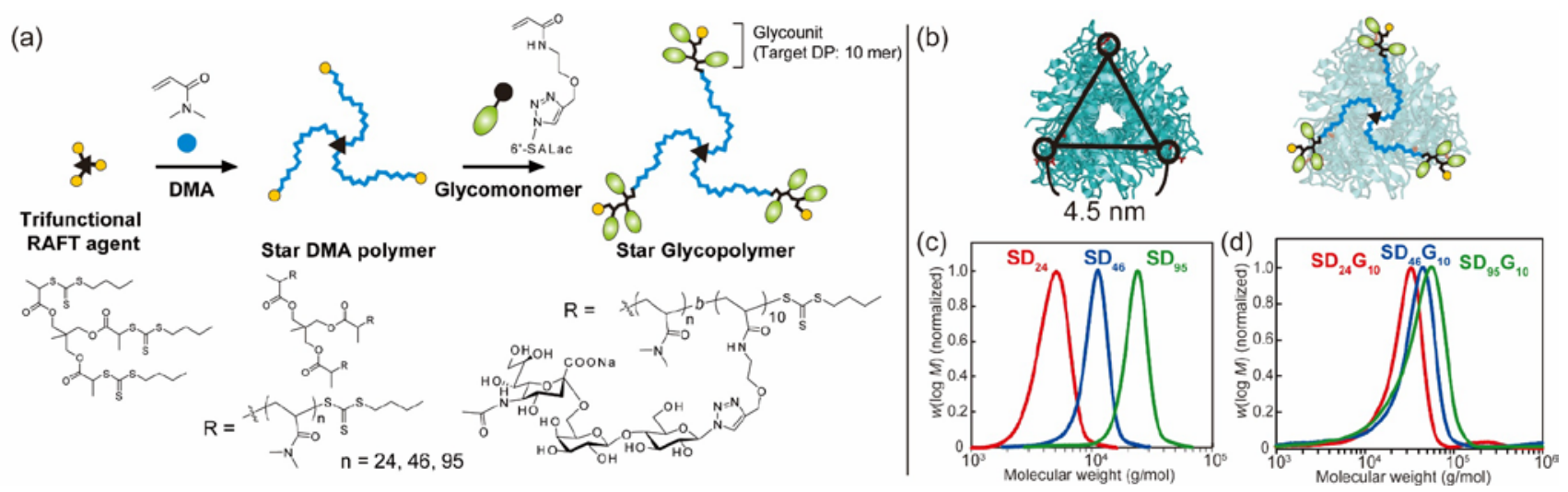

Figure 1. (a) Schematic illustrations of the synthesis of star glycopolymers carrying 6'-sialyllactose units. (b) The structures of hemagglutinin (PDB: 5HMG) (left) and the complex of the star glycopolymer and HA (right). The amino acids involved in the interaction with sialic acids are shown in red. The black circles and triangle indicates the sugar-binding pockets on HA and the distance between two pockets, respectively. (c) SEC chromatographs of the star DMA polymers calibrated by polystyrene standard (DMF with $10 \mathrm{mM} \mathrm{LiBr}$ ). (d) SEC chromatographs of the star glycopolymers calibrated by pullulan standard (100 $\mathrm{mM} \mathrm{NaNO}_{3}(\mathrm{aq})$ ). 
correlation (Figure 2a,b). These indicated that the radical concentration was constant, and that the reaction proceeded as a "living” radical polymerization, respectively. For all polymers, the monomer consumption stopped when the conversion rate reached $\sim 87 \%$ because of the termination reaction that arose from depletion of the monomer in the latter stages of the polymerization. However, no peak attributed to star-star coupling was observed in the size exclusion chromatography (SEC) analysis (Table 1 and Figure 1c) ${ }^{25}$ Considering the minimized feed amount of initiator $(0.02$ eq to the trithiocarbonate of the RAFT agent, Table S1), the intramolecular termination reaction or backbiting reaction happened in the latter stages of the polymerization.
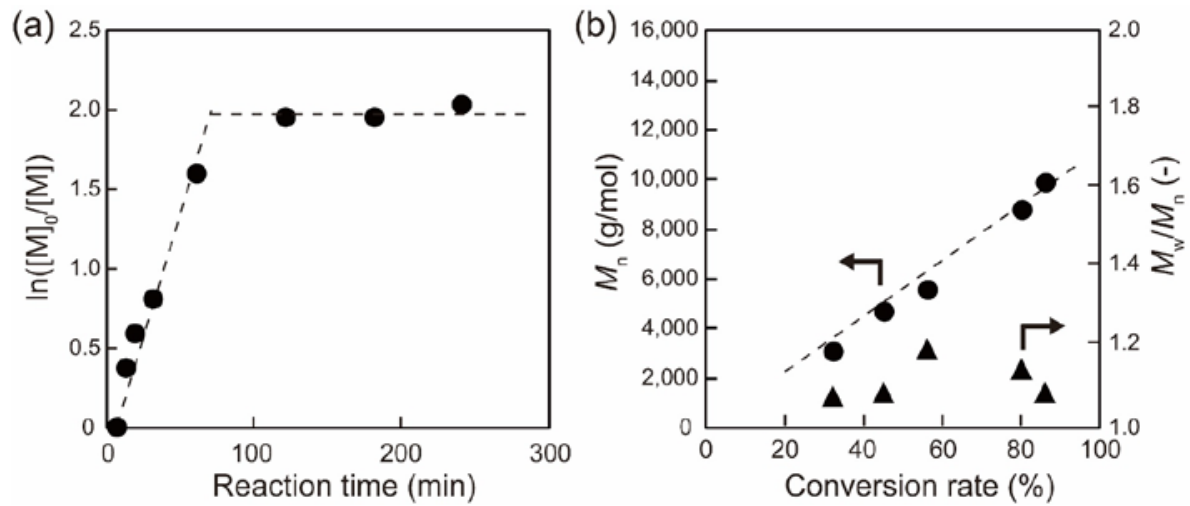

Figure 2. Results of the polymerization for $\mathrm{SD}_{46}$. (a) Plots of $[\mathrm{M}]_{0} /[\mathrm{M}]$ vs reaction time. (b) Plots of molecular weight (circles) and dispersity (triangles) obtained from SEC analysis vs conversion rate.

The glycounit segment was introduced into the star DMA polymers by block copolymerization with the glycomonomer in water. 6'-Sialyllactose (6'-SALac) has a natural ligand structure for HA of human influenza virus (Neu5Ac- $\alpha-(2,6)-\mathrm{Gal})$, and was therefore chosen as the glycounit. The number of the monomer units in the polymer structure that is prepared by RAFT block copolymerization is distributed according to a Poisson distributions, ${ }^{26}$ and the proportion of polymer chains, where no 
glycomonomers were added, increases with decreasing the target DP. To ensure that all polymer arms were functionalized with glycounits, the target DP was set at 10 ([M]: [Trithiocarbonate] $=10: 1)$. The conversion rates were over $99 \%$ for all star glycopolymers $\left(\mathbf{S D}_{\mathbf{n}} \mathbf{G}_{\mathbf{1 0}}\right.$ [n $=24,46$, and 95$]$, Table 1$)$. Although this result of the monomer conversion is not consistent with that of the polymerization of DMA, it can be explained based on the effect of solvent. Polymerization rate of acrylamide-type monomer in water increases due to the hydrogen bonding between the amide carbonyl group and water molecules. ${ }^{27}$ Thus, the glycomonomer in water was more reactive than DMA in DMF, and the polymerization of the glycomonomer completely proceeded in spite of depletion of monomer in the latter stages of the polymerization. In addition, the complete monomer conversion indicated that the steric hindrance of the bulky glycounits among the adjacent propagating polymer arms did not affect the polymerization. The order of the molecular weights from the SEC analysis corresponded to the DP of the DMA blocks in the star glycopolymers (Table 1 and Figure 1d).

The hydrodynamic diameters of the star polymers $\left(D_{\mathrm{h}}\right)$ were determined by dynamic light scattering measurements (Table 1 and Figure S3). The $D_{\mathrm{h}}$ values of the star DMA polymers increased with the DP of DMA, and the same $D_{\mathrm{h}}$ trend was observed after the introduction of the glycounit block segments. This indicates that the size of the star glycopolymers in aqueous solution was controlled by tuning the target DP of the polymer arms. 
Table 1. Properties of RAFT block copolymerization with trifunctional RAFT agent.

\begin{tabular}{|c|c|c|c|c|c|c|c|c|}
\hline \multirow{2}{*}{ Polymer $^{\mathrm{a}}$} & \multirow{2}{*}{$\begin{array}{c}\text { [M]:[Trithio]: } \\
\text { [Ini] }\end{array}$} & Conv. ${ }^{\mathrm{b}}$ & $\mathrm{DP}^{\mathrm{c}}$ & $M_{\mathrm{n}, \mathrm{NMR}}{ }^{\mathrm{d}}$ & $M_{\mathrm{n}, \mathrm{SEC}}{ }^{\mathrm{e}}$ & $M_{\mathrm{n}, \mathrm{LS}}{ }^{\mathrm{e}}$ & \multirow{2}{*}{$M_{\mathrm{w}} / M_{\mathrm{n}}^{\mathrm{e}}$} & $D_{\mathrm{h}}{ }^{\mathrm{f}}$ \\
\hline & & (\%) & (mer) & (g/mol) & $(\mathrm{g} / \mathrm{mol})$ & $(\mathrm{g} / \mathrm{mol})$ & & $(\mathrm{nm})$ \\
\hline $\mathrm{SD}_{24}$ & 30: 1: 0.02 & 80 & 24 & 7,900 & 4,400 & ND & 1.11 & 3.90 \\
\hline $\mathrm{SD}_{46}$ & 50: 1: 0.02 & 86 & 46 & 14,500 & 9,900 & ND & 1.09 & 4.77 \\
\hline $\mathrm{SD}_{95}$ & 100: 1: 0.02 & 87 & 95 & 29,000 & 21,200 & ND & 1.11 & 7.05 \\
\hline $\mathrm{SD}_{24} \mathrm{G}_{10}$ & 10: 1: 0.05 & $>99$ & 35 & 32,900 & 25,200 & 24,900 & 1.20 & 6.65 \\
\hline $\mathrm{SD}_{46} \mathrm{G}_{10}$ & 10: 1: 0.05 & $>99$ & 56 & 39,500 & 35,800 & 35,900 & 1.17 & 7.83 \\
\hline $\mathrm{SD}_{95} \mathrm{G}_{10}$ & 10: 1: 0.05 & $>99$ & 105 & 54,000 & 37,500 & 45,800 & 1.31 & 9.13 \\
\hline
\end{tabular}

(a) The star DMA polymer with DP of 24 is abbreviated as $\mathrm{SD}_{24}$. The star glycopolymer that has 24 units of DMA and 10 units of glycomonomer is abbreviated as $\mathrm{SD}_{24} \mathrm{G}_{10}$. (b) The conversion rate was determined from ${ }^{1} \mathrm{H}$ NMR. (c) The DP of each polymer arm was determined from ${ }^{1} \mathrm{H}$ NMR. (d) The molecular weight was calculated using the equation: $M_{\mathrm{n}, \mathrm{NMR}}=3 \times\left(\mathrm{MW}_{\mathrm{DMA}} \times \mathrm{DP}_{\mathrm{DMA}}+\mathrm{MW}_{\mathrm{Glycounit}} \times \mathrm{DP}_{\mathrm{Glycounit}}\right)+\mathrm{MW}_{\mathrm{RAFT}}$. (e) The molecular weights were determined by size exclusion chromatography (SEC) analysis and light scattering (LS) measurement. Mw/Mn was calculated using the values from SEC analysis. ND indicates "not determined".(f) The hydrodynamic diameter $\left(D_{\mathrm{h}}\right)$ was determined from DLS measurement in $10 \mathrm{mM}$ phosphate buffer solution $(1 \mathrm{~g} / \mathrm{L}, \mathrm{n}=3)$.

To confirm the cross-linked structure of the synthesized star glycopolymers, the ester groups of

SD $_{\mathbf{2 4}} \mathrm{G}_{\mathbf{1 0}}$, which were derived from the trifunctional RAFT agent, were hydrolysed by incubating the polymer solution (0.2 $\mathrm{M} \mathrm{NaOH}$ aqueous solution) at $70{ }^{\circ} \mathrm{C}$ for $1 \mathrm{~h}$. The SEC analysis of the uncrosslinked polymer arms revealed the narrow unimodal peak that was shifted to lower molecular weight than that of $\mathbf{S D}_{24} \mathbf{G}_{10}\left(M_{\mathrm{w}} / M_{\mathrm{n}}=1.09\right.$, Figure 3). Furthermore, the absolute molecular weights of SD $_{\mathbf{2 4}} \mathbf{G}_{\mathbf{1 0}}$ and the uncross-linked polymers, which were determined from light scattering measurement, were 24,900 g/mol and 9,200 g/mol, respectively (Table 1 and Figure 3). SD24G10 had the cross-linked structures, and the molecular weight was three times larger than that of each polymer arm, indicating that the synthesized star glycopolymers have triarm "star” structures. 


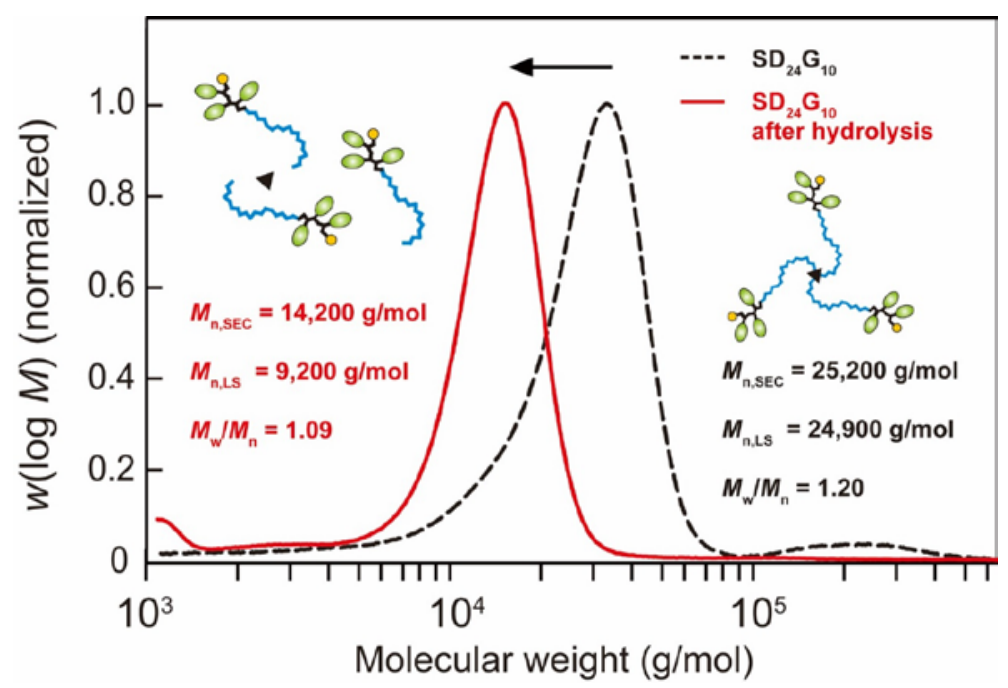

Figure 3. SEC chromatographs of $\mathbf{S D}_{\mathbf{2 4}} \mathbf{G}_{\mathbf{1 0}}$ (black dotted line) and the hydrolyzed $\mathbf{S D}_{\mathbf{2 4}} \mathbf{G}_{\mathbf{1 0}}$ (red line). The values of $M_{\mathrm{w}} / M_{\mathrm{n}}$ were determined from SEC analysis [Eluent: $100 \mathrm{mM} \mathrm{NaNO}_{3}(\mathrm{aq})$, Standard: Pullulan for SEC and polyethylene glycol for LS].

Evaluation of the interaction with the influenza virus.

The interaction of the synthesized star glycopolymers with the influenza virus was evaluated using a hemagglutination inhibition (HI) assay. ${ }^{21,28}$ Fetuin, that is natural glycoprotein, ${ }^{29}$ and $\mathbf{S D}_{\mathbf{4 5}}$, that has no glycounit, were used as the positive and negative controls, respectively. The star glycopoymers and fetuin inhibited the aggregation of red blood cells (RBCs) caused by the virus, demonstrating that the star glycopolymers interacted with HA on the virus (Figure S4). SD45 did not inhibit the aggregation of RBCs, indicating the absence of non-specific interaction between the spacer segment and HA (Figure S4). The minimum polymer concentration for HI was defined as the inhibition constant $\left(K_{\mathrm{i}}\right)$, and the $K_{\mathrm{i}}$ was calculated in terms of glycounit concentration (Figure 4). ${ }^{6}$ The average values of $K_{\mathrm{i}}$ for $\mathbf{S D}_{\mathbf{2 4}} \mathbf{G}_{\mathbf{1 0}}, \mathbf{S D}_{\mathbf{4 6}} \mathbf{G}_{\mathbf{1 0}}, \mathbf{S D}_{\mathbf{9 5}} \mathbf{G}_{\mathbf{1 0}}$, and fetuin (n = 2) were 21, 140, 830, and $49 \mu \mathrm{M}$, respectively (Table 2). The interaction of the monovalent glycounits with HA was evaluated using 6'-SALac $\left(K_{\mathrm{i}}>20 \mathrm{mM}\right.$, 
Figure S4). The lower $K_{\mathrm{i}}$ values of the star glycopolymers indicated that their interactions with HA were stronger than that of 6'-SALac. The interaction of the star glycopolymers with HA was enhanced by the cluster glycoside effect. In particular, the interaction of $\mathbf{S D}_{\mathbf{2 4}} \mathbf{G}_{\mathbf{1 0}}$ with HA was stronger than that of fetuin, demonstrating that optimally designed polymers can be effective virus inhibitor candidates as comparable materials to glycoproteins. In addition, these star glycopolymers did not inhibit the aggregation of RBCs with the influenza virus strain (H1N1) that has selectivity for the Neu5Ac- $\alpha$ (2,3)-Gal structure, not the Neu5Ac- $\alpha-(2,6)-G a l$ structure (Figure S4). ${ }^{30}$ This demonstrates that the selectivity of the glycounits in the star glycopolymers was maintained.

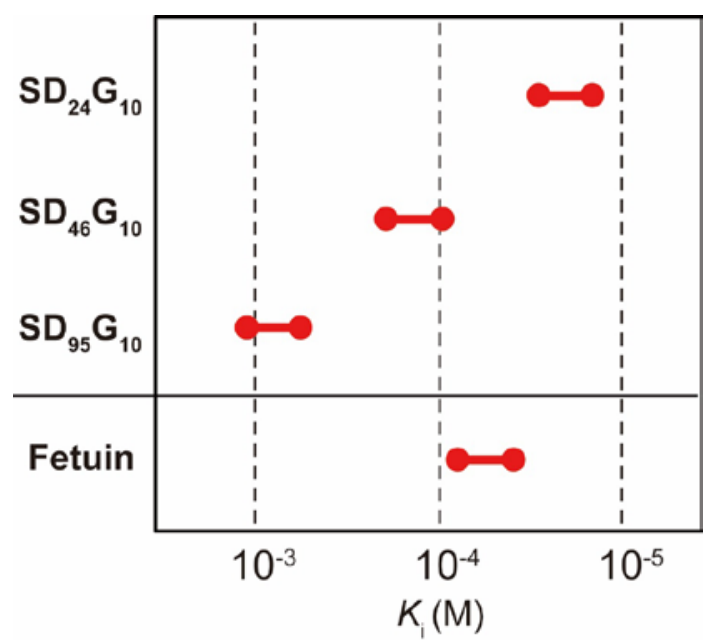

Figure 4. $K_{\mathrm{i}}$ of the star glycopolymers and fetuin against influenza viruses [A/Aichi/2/68 (H3N2)] from the HI assay $(\mathrm{n}=2)$. The unit is sugar concentration.

Estimation of binding modes in the interaction between the star glycopolymers and hemagglutinin.

The binding modes between the star glycopolymers and HA were estimated using the following formula suggested by Whitesides. ${ }^{6}$ 


$$
\begin{gathered}
K_{N}^{\text {poly }}=\left(K^{\text {mono }}\right)^{\alpha N} \\
K_{N}^{\text {poly }}=\beta K^{\text {mono }}
\end{gathered}
$$

Where $K_{N}{ }^{\text {poly }}$ and $K^{\text {mono }}$ indicate the association constants of polyvalent interaction and monovalent interaction, respectively. The number of binding sites in the interaction between a polyvalent ligand and a receptor $(N)$, and the degree of cooperativity $(\alpha)$ are defined. The association constants of the star glycopolymers and 6'-SALac with HA $\left(K_{N}{ }^{\text {poly }}\right.$ and $\left.K^{\text {mono }}\right)$ were calculated as the inverse of the $K_{\mathrm{i}}$ ( $K_{\mathrm{i}}$ of 6'-SALac was assumed to be $20 \mathrm{mM}$ ). The $N$ for the star glycopolymers was calculated from formula (1) assuming $\alpha=1$ (Table 2 and a rationale is provided in the Supporting Information). The $N$ of $\mathbf{S D}_{\mathbf{2 4}} \mathrm{G}_{\mathbf{1 0}}, \mathbf{S D}_{\mathbf{4 6}} \mathbf{G}_{\mathbf{1 0}}$, and $\mathbf{S D}_{\mathbf{9 5}} \mathbf{G}_{\mathbf{1 0}}$ were estimated to be 2.7, 2.3, and 1.8, respectively. As one HA molecule has three sugar-binding pockets, these values were considered reasonable. The synthesized star glycopolymers interacted with HA thorough the multiple binding sites reflecting the topological design of the molecules (Figure 5). This discussion is based on the assumption that one star glycopolymer molecule interacted with one HA molecule (a rationale is provided in the Supporting Information). In Figure 5, the polymer arms are stretched out, and the all glycounits are arranged toward the outside of the star polymer molecule. However, the structures of the star glycopolymers were not rigid in this work, and it was possible that the long polymer arms wrapped some of the glycounits.

To verify the accuracy of the formula (1), the interaction of the star glycopolymers with another 
Table 2. Summary of the constants calculated with $K_{\mathrm{i}}$ for HA and hydrodynamic diameters of the star glycopolymers.

\begin{tabular}{|c|c|c|c|c|c|}
\hline \multirow{2}{*}{ Polymer } & $K_{\mathrm{i}}$ & $K_{N}{ }^{\text {poly }}$ & $N^{\mathrm{a}}$ & $\beta^{\mathrm{b}}$ & $\rho_{\mathrm{G}}{ }^{\mathrm{c}}$ \\
\cline { 2 - 6 } & $(\mathrm{M})$ & $\left(\mathrm{M}^{-1}\right)$ & $(-)$ & $(-)$ & $\left(\mathrm{unit} / \mathrm{nm}^{2}\right)$ \\
\hline $\mathbf{S D}_{\mathbf{2 4}} \mathbf{G}_{\mathbf{1 0}}$ & $2.1 \times 10^{-5}$ & 47620 & 2.7 & 952 & 0.22 \\
\hline $\mathbf{S D}_{4 \mathbf{6}} \mathbf{G}_{\mathbf{1 0}}$ & $1.4 \times 10^{-4}$ & 7140 & 2.3 & 143 & 0.16 \\
\hline $\mathbf{S D}_{\mathbf{9 5}} \mathbf{G}_{\mathbf{1 0}}$ & $8.3 \times 10^{-4}$ & 1210 & 1.8 & 24 & 0.11 \\
\hline
\end{tabular}

The association constant was calculated using the formula: $K_{N}{ }^{\text {poly }}=1 / K_{\mathrm{i}}$. (a) $N$ was determined using the formula $K_{N}{ }^{\text {poly }}=\left(K^{\text {mono }}\right)^{\alpha N}$, assuming $\alpha=1$ and $K^{\text {mono }}=50 \mathrm{M}^{-1}$ from $K_{\mathrm{i}}$ of 6'-SALac. (b) $\beta$ was determined using formula: $K_{N}{ }^{\text {poly }}=\beta K^{\text {mono }}$. (c) The glycounit density on the molecular surface was calculated using following formula: $\rho_{\mathrm{G}}=$ the number of glycounits in the star glycopolymer molecule (30 units)/surface area $(S)$, where $S=\pi D_{\mathrm{h}}{ }^{2}$.

lectin (sambucus sieboldiana agglutinin, SSA) was evaluated (Figure S5). A monovalent interaction between the star glycopolymers and SSA $(N=1)$ was expected because the distance between the two sugar-binding pockets of SSA is greater than the diameters of the star glycopolymers (Table 1 and Figure S6, PDB: 1rzo). ${ }^{31}$ As anticipated, the estimated $N$ of $\mathbf{S D}_{\mathbf{2 4}} \mathbf{G}_{\mathbf{1 0}}, \mathbf{S D}_{\mathbf{4 6}} \mathbf{G}_{\mathbf{1 0}}$, and $\mathbf{S D}_{\mathbf{9 5}} \mathbf{G}_{\mathbf{1 0}}$ in the interaction with SSA was close to 1 (Table S2). This supported the estimation for the interaction with HA, and indicated that the synthesized star glycopolymers interacted with HA and SSA through multiple-site and one-site binding modes, respectively, depending on the distance between the sugarbinding pockets on the lectins. The binding modes of the star glycopolymers with the lectins were controlled by tuning the length of the polymer arms, that is, the spatial arrangement of the glycounits. Interestingly, this result is not consistent with that of the work by Stenzel and co-workers, ${ }^{32}$ where the clear correlation between the structure of star glycopolymers and the interaction with a plant lectin was not observed. It is considered to be due to the different molecular mobility of the star polymers. The influence both of the polymer component (monomer type and bulkiness of the side chains) and of the 
topological structure (the number of polymer arms) on the interaction with target lectins can be factors, and is under investigation.
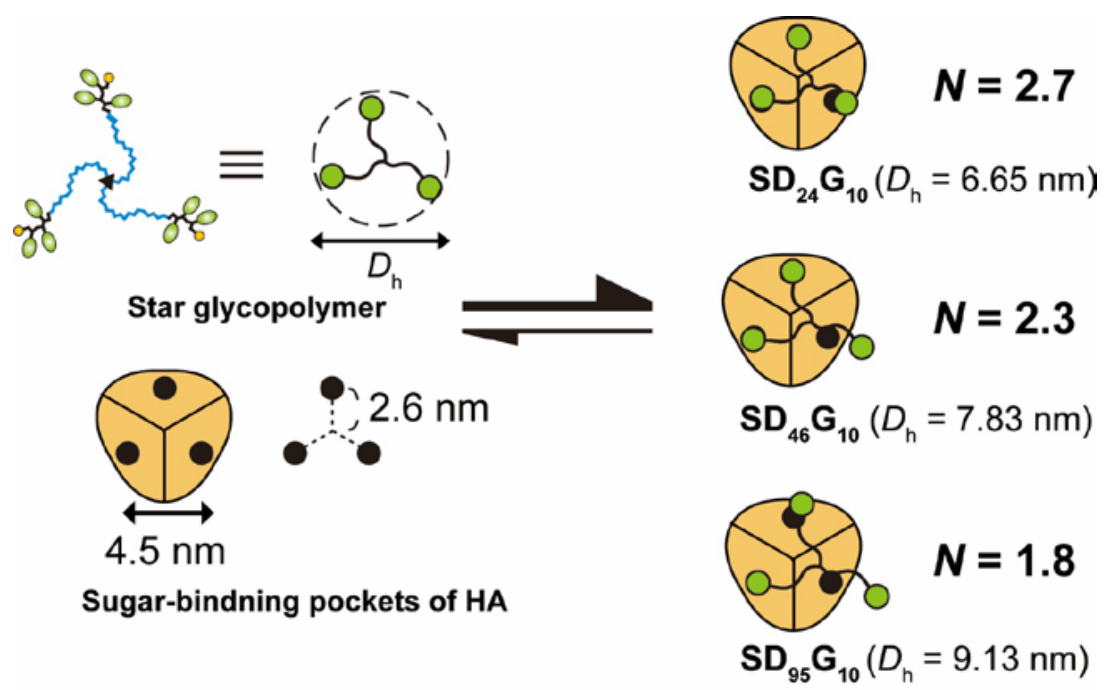

Figure 5. Illustration of the expected binding modes between the star glycopolymers and HA. $D_{\mathrm{h}}$ and $N$ indicate the hydrodynamic diameters and the number of binding sites for each polymer, respectively.

An enhancement factor $\beta$ was also calculated based on formula (2). The values of $\beta$ for $\mathbf{S D}_{\mathbf{2 4}} \mathbf{G}_{\mathbf{1 0}}$, $\mathbf{S D}_{\mathbf{4 6}} \mathbf{G}_{\mathbf{1 0}}$, and $\mathbf{S D}_{\mathbf{9 5}} \mathbf{G}_{\mathbf{1 0}}$ for the interaction with HA were above 952, 143, and 24, respectively. While the number of the glycounits in the star glycopolymers was the same (30 units), $\beta$ was different for each star glycopolymer. The efficiency of the glycounits in the interactions was studied in terms of glycounit density on the molecular surface $\left(\rho_{\mathrm{G}}\right)$, which was calculated using the $D_{\mathrm{h}}$ of the polymers assuming the star glycopolymer molecules to be spherical. The $\rho_{\mathrm{G}}$ of the glycopolymers was $0.22,0.16$, and 0.11 unit/nm² , for $\mathbf{S D}_{\mathbf{2 4}} \mathbf{G}_{\mathbf{1 0}}$, $\mathbf{S D}_{\mathbf{4 6}} \mathbf{G}_{\mathbf{1 0}}$, and $\mathbf{S D}_{\mathbf{9} 5} \mathbf{G}_{\mathbf{1 0}}$, respectively (Table 2). The star glycopolymer with the highest $\rho_{\mathrm{G}}$ showed the highest $\beta$ in the interaction with HA. Conversely, the $\beta$ decreased as $\rho_{\mathrm{G}}$ increased for the interaction with SSA (Table S2). This indicates that $\rho_{\mathrm{G}}$ is not the only factor that 
determines the interaction of the star glycopolymers with lectins, and the multivalent interaction with the target is more important, demonstrating that the design of the spatial arrangement of the glycounits toward the sugar-binding pockets of the target lectin is essential in creating effective biological ligands. ${ }^{33-35}$

\section{Conclusion}

In summary, we synthesized star glycopolymers functionalized with 6'-siallyllactose by RAFT block copolymerization. The structures of the star glycopolymers were well-defined, and the hydrodynamic diameters correlated with their DMA block segment DP. The star glycopolymers interacted with the H3N2 influenza virus showing the specificity of the glycounits in the polymer structures. The spatial arrangement of the glycounits toward the sugar-binding pockets of the lectins had a greater effect than the density of the glycounits on the molecular surface. This work is demonstrating that the topological design of glycopolymer-ligands can be achieved using CRP techniques, and their interactions can be tuned for the development of synthetic nanomedicine. This contributes to establishing the design criteria for achieving synthetic polymers that are comparable to natural biopolymers such as DNA and peptides. We hope that synthetic polymers will open up new opportunities in biotechnology.

\section{Experimental Section}

2-\{[(Butylsulfanyl)carbonothioyl]sulfanyl $\}$ propanoic acid (BTPA), ${ }^{36}$ 6'-sialyllactose azide (6' -SALac 
azide), ${ }^{37,38}$ and tris(benzyltriazolylmethyl)amine (TBTA) ${ }^{39}$ were prepared according to previous papers.

Synthesis of 2-(((2-(((butylthio)carbonothioyl)thio)propanoyl)oxy)methyl)-2-methylpropane-1,3-diyl bis(2-(((butylthio)carbonothioyl)thio)propanoate) (trifunctional RAFT agent).

To the solution of BTPA (4.46 g, $18.7 \mathrm{mmol})$, trimethylolethane (500 mg, $4.16 \mathrm{mmol}$ ), and DMAP (212 mg, $1.73 \mathrm{mmol})$ in dry $\mathrm{CH}_{2} \mathrm{Cl}_{2}(60 \mathrm{~mL}), \mathrm{EDC} \cdot \mathrm{HCl}(2.39 \mathrm{~g}, 12.48 \mathrm{mmol})$ was added at $0{ }^{\circ} \mathrm{C}$ (the color changed to red from yellow). After stirring for $10 \mathrm{~min}$, the ice bath was removed and the solution was kept stirring at room temperature for $18 \mathrm{~h}$. The progress of the reaction was confirmed on TLC (EtOAc: Hexane = 1: 1). The organic phase was washed with $1 \mathrm{wt} \% \mathrm{HCl}(\mathrm{aq})(120 \mathrm{~mL} \times 3)$, MilliQwater $(120 \mathrm{~mL} \times 2)$, and dried with $\mathrm{Na}_{2} \mathrm{SO}_{4}$. The filtrate was concentrated under reduced pressure, and purified by column chromatography (EtOAc: Hexane $\left.=1: 1, \mathrm{R}_{\mathrm{f}}=0.9\right)$. The product was obtained as yellow oil (2.56 g, 79\%). ${ }^{1} \mathrm{H}$ NMR (400 MHz, $\left.\mathrm{CDCl}_{3}\right) \delta$ in ppm: 4.85 (q, 3H, ester-CH(CH 3$)-S$ ), 4.00 (m, 6H, $\mathrm{CH}_{3}-\left(\mathrm{CH}_{2}-\right.$ ester-) $)$ ), 3.37 (ddd, 6H, $-\mathrm{S}-\mathrm{CH}_{2}-\mathrm{C}_{3} \mathrm{H}_{7}$ ), 1.69 (quin, 6H, $-\mathrm{SCH}_{2}-\mathrm{CH}_{2}-\mathrm{C}_{2} \mathrm{H}_{5}$ ), 1.60 (d, 9H, ester-CH(CH 3$)-S), 1.44$ (sext, 6H, $\left.-\mathrm{SC}_{2} \mathrm{H}_{4}-\mathrm{CH}_{2}-\mathrm{CH}_{3}\right), 1.00$ (s, 3H, $\left.\mathrm{CH}_{3}-\left(\mathrm{CH}_{2}-\mathrm{ester}-\right)_{3}\right)$, 0.95 (t, 9H, $\left.\mathrm{SC}_{3} \mathrm{H}_{6}-\mathrm{CH}_{3}\right) .{ }^{13} \mathrm{C}$ NMR (400 MHz, $\left.\mathrm{CDCl}_{3}\right) \delta$ in ppm: $222.0(\mathbf{C}=\mathrm{S}), 170.8(\mathbf{C}=\mathrm{O}), 66.7$ $(\mathbf{C}-\mathrm{O}-\mathrm{C}=\mathrm{O}), 47.5$ (ester- $\left.\left(\mathrm{CH}_{3}\right) \mathbf{C H}-\mathrm{S}\right), 38.7\left(\left(\mathrm{CH}_{3}\right) \mathbf{C}-(\text { ester- })_{3}\right), 37.1$ (-S-C-C$\left.{ }_{3} \mathrm{H}_{7}\right), 30.0(-\mathrm{SC}-\mathbf{C}-$ $\left.\mathrm{C}_{2} \mathrm{H}_{5}\right), 22.2$ (-SC $\left.2-\mathbf{C}-\mathrm{CH}_{3}\right), 17.0\left(\left(\mathbf{C H}_{3}\right) \mathrm{CH}-(\text { ester- })_{3}\right), 16.6$ (ester- $\left.\left(\mathbf{C H}_{3}\right) \mathrm{CH}-\mathrm{S}\right), 13.7\left(\mathrm{SC}_{3}-\mathbf{C H}_{3}\right)$. Mass Spectrometry (+ESI-MS) m/z: $803.41[\mathrm{M}+\mathrm{Na}]$. 
Synthesis of 2-(2-propynyloxy)ethyl acrylamide.

To the solution of 2-(2-propynyloxy)ethylamine (2 g, $20.2 \mathrm{mmol}$ ) and DIPEA (3.45 mL, $20.2 \mathrm{mmol}$ ) in dry $\mathrm{CH}_{2} \mathrm{Cl}_{2}(32 \mathrm{~mL})$, acryloyl chloride $(1.71 \mathrm{~mL}, 21.2 \mathrm{mmol})$ in dry $\mathrm{CH}_{2} \mathrm{Cl}_{2}(4 \mathrm{~mL})$ was slowly dropped at $0{ }^{\circ} \mathrm{C}$. The solution was kept stirring at room temperature for $20 \mathrm{~h}$. The progress of the reaction was confirmed on TLC (EtOAc: hexane $=2: 1)$. The solution was concentrated under reduced pressure, and purified by column chromatography (EtOAc: hexane $=2: 1$ ). The product was obtained as pale yellow liquid ( $2.76 \mathrm{~g}, 89 \%$ ), and preserved at $-20{ }^{\circ} \mathrm{C}$ with a small amount of hydroquinone.

${ }^{1} \mathrm{H}$ NMR (400 MHz, $\left.\mathrm{CDCl}_{3}\right) \delta$ in ppm: 6.29 (dd, $1 \mathrm{H}$, trans $\mathrm{CH}_{2}=\mathrm{CH}$ ), 6.10 (dd, $1 \mathrm{H}, \mathrm{CH}_{2}=\mathrm{CH}$ ), 5.99 (br, $1 \mathrm{H}$, Amide), 5.65 (dd, $1 \mathrm{H}$, cis $\mathrm{CH}_{2}=\mathrm{CH}$ ), 4.17 (d, 2H, O-CH $\left.\mathrm{CH}_{2}-\mathrm{C} \equiv\right), 3.64$ (t, 2H, $\mathrm{HN}-\mathrm{CH}_{2}-\mathrm{CH}_{2}-$ O), $3.57\left(\mathrm{t}, 2 \mathrm{H}, \mathrm{HN}-\mathrm{CH}_{2}-\mathrm{CH}_{2}-\mathrm{O}\right), 2.46(\mathrm{t}, 1 \mathrm{H},-\mathrm{C} \equiv \mathrm{CH}) .{ }^{13} \mathrm{C} \mathrm{NMR}\left(400 \mathrm{MHz}, \mathrm{CDCl}_{3}\right) \delta$ in ppm: $165.7(\mathrm{C}=\mathrm{O}), 130.9\left(\mathrm{CH}_{2}=\mathbf{C H}\right), 126.6\left(\mathrm{CH}_{2}=\mathrm{CH}\right), 79.4(-\mathbf{C} \equiv \mathrm{CH}), 75.0(-\mathrm{C} \equiv \mathbf{C H}), 68.7(-\mathrm{C}-\mathbf{C}-\mathrm{O})$, $58.4(\mathrm{O}-\mathrm{C}-\mathrm{C} \equiv \mathrm{CH}), 39.2(\mathrm{HN}-\mathrm{C}-\mathrm{C})$. Mass Spectrometry (+ESI-MS) m/z: 329.18 [2M+Na].

Synthesis of 6'-sialyllactose acrylamide (6'-SALacAAm).

TBTA (80 mg, $0.15 \mathrm{mmol}$ ) was dissolved in $\mathrm{MeOH}(15 \mathrm{~mL})$, and $\mathrm{CuSO}_{4}(24 \mathrm{mg}, 0.15 \mathrm{mmol})$ in $\mathrm{H}_{2} \mathrm{O}$ (1 mL) was added. The solution of 6'-SALac azide (1.0 g, $1.52 \mathrm{mmol})$ and 2-(2-propynyloxy)ethyl acrylamide (221 mg, $1.44 \mathrm{mmol})$ in $\mathrm{H}_{2} \mathrm{O}(13 \mathrm{~mL}$ ) was added, and the oxygen was removed by nitrogen bubbling for $15 \mathrm{~min}$. $\mathrm{L} \cdot \mathrm{Asc} \cdot \mathrm{Na}(30 \mathrm{mg}, 0.15 \mathrm{mmol})$ in $\mathrm{H}_{2} \mathrm{O}(1 \mathrm{~mL})$ was added by syringe, and the solution was kept stirring at room temperature for $18 \mathrm{~h}$ under nitrogen atmosphere. The progress of the 
reaction was confirmed on TLC $\left(\mathrm{H}_{2} \mathrm{O}: \mathrm{MeCN}=1\right.$ : 5). The solution was concentrated, and the precipitation was filtered. The crude product was purified by reverse-phase chromatography (gradient from water to methanol). The product was obtained as white solid after freeze-drying (719 mg, 60\%). ${ }^{1} \mathrm{H}$ NMR (400 MHz, $\mathrm{D}_{2} \mathrm{O}$ ) $\delta$ in ppm: 8.18 (s, $1 \mathrm{H}$, triazole), 6.15 (dd, $1 \mathrm{H}$, trans $\mathrm{CH}_{2}=\mathrm{CH}$ ), 6.10 (dd,

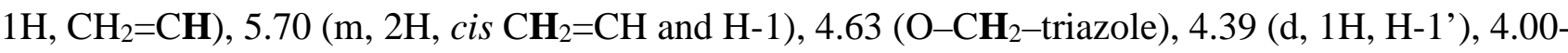
3.45 (m, 23H, sugar-H and $\mathrm{HN}-\mathrm{CH}_{2}-\mathrm{CH}_{2}-\mathrm{O}$ ), 3.39 (t, 2H, $\left.\mathrm{HN}-\mathrm{CH}_{2}-\mathrm{CH}_{2}-\mathrm{O}\right), 2.63$ (dd, $1 \mathrm{H}, \mathrm{H}-3$ ”” ${ }_{\text {eq }}$ ), 1.92 (s, 3H, NHCO-CH 3 ), 1.65 (t, 1H, H-3”, $\left.{ }_{a x}\right) .{ }^{13} \mathrm{C}$ NMR $\left(400 \mathrm{MHz}, \mathrm{D}_{2} \mathrm{O}\right) \delta$ in ppm: $174.9(\mathrm{O}=\mathbf{C}-$ ONa), $173.5\left(\mathrm{CH}_{3}-\mathrm{CONH}\right), 168.8\left(\mathbf{C O N H}\right.$, amide), $144.3\left(\mathrm{C}=\mathrm{C}(\mathrm{NH})-\mathrm{CH}_{2}-\mathrm{O}\right.$, triazole $), 129.9$ $\left(\mathrm{CH}_{2}=\mathbf{C H}\right), 127.4\left(\mathrm{CH}_{2}=\mathrm{CH}\right), 124.2$ (sugar-N-C=C, triazole), 103.3 (C-1'), 100.3 (C-2'), 87.2 (C-1), 78.7, 77.6, 74.8, 73.8, 72.6, 72.4, 71.9, 70.8, 68.6 (sugar-C), 68.4 (HN-C-C-O), 68.2 (-O-C-triazole), 63.7, 62.7 (C-6’ and C-9”), 60.0 (C-6), 51.8 (C-5”), 40.2 (C-3”), 39.1 (HN-C-C-O), 22.1 (NHCO$\mathrm{CH}_{3}$ ). Mass Spectrometry (+ESI-MS) m/z: 834.59 [M+H], 856.60 [M+Na].

Preparation of triarm DMA polymers ( $S D_{24}, S D_{46}$, and $\left.S D_{95}\right)$. $N, N$-Dimethylacrylamide (DMA), the trifunctional RAFT agent, and AIPD were dissolved in the solvent $(\mathrm{DMF}$ : water $=95: 5)$. The monomer concentration and the ratio of reactants are shown in Table S1. The ratio of [Trithio]: [Initiator] $=1: 0.02$. The solution was prepared in a glass tube, and degassed by freeze-thaw cycles (three times). The glass tube was sealed and put in an oil bath. The reaction proceeded at $70{ }^{\circ} \mathrm{C}$ for $3 \mathrm{~h}$. The reaction was stopped by exposing the solution to air. The 
monomer conversion was determined using ${ }^{1} \mathrm{H}$ NMR measurement. The polymer solutions were diluted with $\mathrm{MeOH}\left(0.8 \mathrm{~mL}\right.$ ), and precipitated in $\mathrm{Et}_{2} \mathrm{O}$ (twice). The polymers were dried in vacuo, and obtained as yellow powder.

${ }^{1} \mathrm{H}$ NMR (400 MHz, $\mathrm{D}_{2} \mathrm{O}$ ) $\delta$ in ppm: 3.93 (brs, $\mathrm{CH}_{3}-\left(\mathrm{CH}_{2}-\text { ester-) }\right)_{3}$ ), 3.34 (brs $-\mathrm{S}-\mathrm{CH}_{2}-\mathrm{C}_{3} \mathrm{H}_{7}$ ), 3.10$2.70\left(\mathrm{CON}\left(\mathrm{CH}_{3}\right)_{2}\right.$ and $\left.-\mathrm{SCH}_{2}-\mathrm{C}_{2} \mathbf{H}_{4}-\mathrm{CH}_{3}\right), 2.70-2.30$ (brs, $-\mathrm{CH}-$ main chain), 1.75-1.20 (brd, $-\mathrm{CH}_{2}-$ main chain), 1.03 (ester-CH(CH 3$)-S), 0.96\left(\mathrm{CH}_{3}-\left(\mathrm{CH}_{2}-\text { ester- }\right)_{3}\right), 0.80\left(\mathrm{SC}_{3} \mathrm{H}_{6}-\mathrm{CH}_{3}\right)$.

Preparation of triarm glycopolymers $\left(S D_{24} G_{10}, S D_{46} G_{10}\right.$, and $\left.S D_{95} G_{10}\right)$.

StarDMA, 6'-SALacAAm, and AIPD were dissolved in water, and this solution was prepared in a glass tube. The general procedure is the same as the preparation of StarDMA. The polymer solutions were dialyzed against water for $6 \mathrm{~h}$, and freeze-dried to obtain the products.

${ }^{1} \mathrm{H}$ NMR (400 MHz, $\mathrm{D}_{2} \mathrm{O}$ ) $\delta$ in ppm: 8.18 (s, triazole), 5.68 (s, H-1), 4.54 (s, O-CH ${ }_{2}$-triazole), 4.39 (d, H-1'), 4.05-3.42 (m, sugar-H and HN-CH $2-\mathrm{CH}_{2}-\mathrm{O}$ ), 3.08-2.35 [br, $\mathrm{CON}\left(\mathrm{CH}_{3}\right)_{2}, \mathrm{H}-3$ ”, $-\mathrm{CH}-$ (main chain), and $-\mathrm{SCH}_{2}-\mathrm{C}_{2} \mathrm{H}_{4}-\mathrm{CH}_{3}$ ], 1.92 (s, 3H, $\mathrm{NHCO}-\mathrm{CH}_{3}$ ), 1.75-1.12 [brd, $\mathrm{H}-3$ ") ax and $-\mathrm{CH}_{2}-$ (main chain)], 1.05 (brs, ester- $\left.\mathrm{CH}\left(\mathrm{CH}_{3}\right)-\mathrm{S}\right), 0.97$ (brs, $\left.\mathrm{CH}_{3}-\left(\mathrm{CH}_{2}-\text { ester-) }\right)_{3}\right), 0.71$ (brs, $\mathrm{SC}_{3} \mathrm{H}_{6}-\mathrm{CH}_{3}$ ).

Cleavage of polymer arms of triarm glycopolymers.

$\mathbf{S D}_{24} \mathrm{G}_{10}(2 \mathrm{mg})$ was dissolved in $\mathrm{NaOH}$ aq $(0.2 \mathrm{M}, 500 \mu \mathrm{L})$, and incubated at $70^{\circ} \mathrm{C}$ for $1 \mathrm{~h}$. Then, $\mathrm{HCl}$ aq $(0.2 \mathrm{M}, 500 \mu \mathrm{L})$ was added to neutralize the solution. The sample was used for SEC and LS without 
purification.

Hemagglutination inhibition (HI) assay.

Phosphate-buffered saline (PBS) was added into a 96-well plate (25 $\mu \mathrm{L} /$ well) except the first lane. Glycopolymer solution ( $2 \mathrm{mg} / \mathrm{mL}, 50 \mu \mathrm{L}$ ) was injected in the first lane. The solution in the first lane were diluted by two steps (25 $\mu \mathrm{L})$. Influenza virus solution [A/Aichi/2/68 (H3N2) or A/Puerto Rico/8/34 (H1N1), 4 HAU] was injected in each well (25 $\mu \mathrm{L} /$ well). The 96-well plate was incubated for $1 \mathrm{~h}$ at $4{ }^{\circ} \mathrm{C}$. Red blood cells in the purchased blood cell suspension were washed by centrifugation with PBS three times. The concentrated red blood cells were resuspended in PBS (0.5 v/v\%) and was injected in each well $(50 \mu \mathrm{L})$. The 96-well plate was incubated for $2 \mathrm{~h}$ at $4{ }^{\circ} \mathrm{C}(\mathrm{n}=2)$. Precipitation of red blood cells was determined by visual inspection.

\section{Supporting Information}

Materials, characterization, ${ }^{1} \mathrm{H}$ and ${ }^{13} \mathrm{C}$ NMR spectra of the compounds (Figure S1), the detailed condition of the RAFT polymerization (Table S1), the SEC chromatographs (Figure S2), the data of DLS measurements, the results of hemagglutination inhibition assay (Figure S4, S5, and Table S2), and image of SSA on RasMol software (Figure S6) are available in the Supporting Information.

Notes: 
The authors declare no competing financial interest.

\section{Acknowledgment}

We acknowledge financial support from a Grant-in-Aid for Scientific Research (B) (JP15H03818) and

a Grant-in-Aid for Scientific Research on Innovative areas (JP18H04420).

\section{Reference:}

1. Lutz, J.-F., Lehn, J., Meijer, E. W., and Matyjaszewski, K. (2016) From precision polymers to complex materials and systems. Nat. Rev. Mater. 1, 16024.

2. Grubbs, R. B., and Grubbs, R. H. (2017) 50th Anniversary Perspective: Living PolymerizationEmphasizing the Molecule in Macromolecules. Macromolecules 50, 6979-6997.

3. Polymeropoulos, G., Zapsas, G., Ntetsikas, K., Bilalis, P., Gnanou, Y., and Hadjichristidis, N. (2017) 50th Anniversary Perspective: Polymers with Complex Architectures. Macromolecules 50, 12531290.

4. Ouchi, M., and Sawamoto, M. (2017) 50th Anniversary Perspective: Metal-Catalyzed Living Radical Polymerization: Discovery and Perspective. Macromolecules 50, 2603-2614.

5. Perrier, S. (2017) 50th Anniversary Perspective: RAFT Polymerization-A User Guide. Macromolecules 50, 7433-7447.

6. Mammen, M., Choi, S.-K., and Whitesides, G. M. (1998) Polyvalent Interactions in Biological Systems: Implications for Design and Use of Multivalent Ligands and Inhibitors. Angew. Chem. Int. Ed. 37, 2754-2794.

7. Cecioni, S., Imberty, A., and Vidal, S. (2015) Glycomimetics versus Multivalent Glycoconjugates for the Design of High Affinity Lectin Ligands. Chem. Rev. 115, 525-561.

8. Bhatia, S., Camacho, L. C., and Haag, R. (2016) Pathogen Inhibition by Multivalent Ligand Architectures. J. Am. Chem. Soc. 138, 8654-8666.

9. Lundquist, J. J., and Toone, E. J. (2002) The Cluster Glycoside Effect. Chem. Rev. 102, 555-578.

10. Kitov, P. I., and Bundle, D. R. (2003) On the Nature of the Multivalency Effect: A Thermodynamic Model. J. Am. Chem. Soc. 125, 16271-16284.

11. Huskens, J., Mulder, A., Auletta, T., Nijhuis, C. A., Ludden, M. J. W., and Reinhoudt, D. N. (2004) A Model for Describing the Thermodynamics of Multivalent Host-Guest Interactions at Interfaces. J. Am. Chem. Soc. 126, 6784-6897.

12. Kotani, S., and Hughes, W. L. (2017) Multi-Arm Junctions for Dynamic DNA Nanotechnology. J. Am. Chem. Soc. 139, 6363-6368.

13. Matsuurua, K. (2014) Rational design of self-assembled proteins and peptides for nano- and micro- 
sized architectures. RSC Adv. 4, 2942-2953.

14. Fleming, S., and Ulijn, R. V. (2014) Design of nanostructures based on aromatic peptide amphiphiles. Chem. Soc. Rev. 43, 8150-8177.

15. Matsuura, K., Hibino, M., Yamada, Y., and Kobayashi, K. (2001) Construction of Glyco-Clusters by Self-Organization of Site-Specifically Glycosylated Oligonucleotides and Their Cooperative Amplification of Lectin-Recognition. J. Am. Chem. Soc. 123, 357-358.

16. Sauter, N. K., Hanson, J. E., Glick, G. D., Brown, J. H., Crowther, R. L., Park, S. J., Skehel, J. J., and Wiley, D. C. (1992) Binding of Influenza Virus Hemagglutinin to Analogs of Its Cell-Surface Receptor, Sialic Acid: Analysis by Proton Nuclear Magnetic Resonance Spectroscopy and X-ray Crystallography. Biochemistry 31, 9609-9621.

17. Sassaki, G. L., Elli, S., Rudd, T. R., Macchi, E., Yates, E., Naggi, A., Shriver, Z., Raman, R., Sasisekharan, R., Torri, G., et al. (2013) Human $(\alpha 2 \rightarrow 6)$ and Avian $(\alpha 2 \rightarrow 3)$ Sialylated Receptors of Influenza A Virus Show Distinct Conformations and Dynamics in Solution. Biochemistry 52, 7217-7230.

18. Waldmann, M., Jirman, R., Hoelscher, K., Wienke, M., Niemeyer, F. C., Rehders, D., and Meyer, B. (2014) A Nanomolar Multivalent Ligand as Entry Inhibitor of the Hemagglutinin of Avian Influenza. J. Am. Chem. Soc. 136, 783-788.

19. Yamabe, M., Kaihatsu, K., and Ebara, Y. (2018) Sialyllactose-Modified Three-Way Junction DNA as Binding Inhibitor of Influenza Virus Hemagglutinin. Bioconjug. Chem. 29, 1490-1494.

20. Kosono, S., Kasai, A., Komaba, S., Matsubara, T., Sato, T., Takahashi, D., and Toshima, K. (2018) Novel hemagglutinin-binding sulfated oligofucosides and their effect on influenza virus infection. Chem. Commun. 54, 7467-7470.

21. Sigal, G. B., Mammen, M., Dahmann, G., and Whitesides, G. M. (1996) Polyacrylamides Bearing Pendant $\alpha$-Sialoside Groups Strongly Inhibit Agglutination of Erythrocytes by Influenza Virus: The Strong Inhibition Reflects Enhanced Binding through Cooperative Polyvalent Interactions. J. Am. Chem. Soc. 118, 3789-3800.

22. Tang, S., Puryear, W. B., Seifried, B. M., Dong, X., Runstadler, J. A., Ribbeck, K., and Olsen, B. D. (2016) Antiviral Agents from Multivalent Presentation of Sialyl Oligosaccharides on Brush Polymers. ACS Macro Lett. 5, 413-418.

23. Nagao, M., Fujiwara, Y., Matsubara, T., Hoshino, Y., Sato, T., and Miura, Y. (2017) Design of Glycopolymers Carrying Sialyl Oligosaccharides for Controlling the Interaction with the Influenza Virus. Biomacromolecules 18, 4385-4392.

24. Huang, M. L., Cohen, M., Fisher, C. J., Schooley, R. T., Gagneux, P., and Godula, K. (2015) Determination of receptor specificities for whole influenza viruses using multivalent glycan arrays. Chem. Commun. 51, 5326-5329.

25. Ren, J. M., McKenzie, T. G., Fu, Q., Wong, E. H. H., Xu, J., An, Z., Shanmugam, S., Davis, T. P., Boyer, C., and Qiao, G. G. (2016) Star Polymers. Chem. Rev. 116, 6743-6836.

26. Gody, G., Zetterlund, P. B., Perrier, S., Harrisson, S. (2016) The limits of precision monomer 
placement in chain growth polymerization. Nat. Commun. 7, 10514.

27. Valdebenito, A., and Encinas, M. V. (2010) Effect of solvent on the free radical polymerization of N,N-dimethylacrylamide. Polym. Int. 59, 1246-1251.

28. Bandlow, V., Liese, S., Lauster, D., Ludwig, K., Netz, R. R., Herrmann, A., and Seitz, O. (2017) Spatial Screening of Hemagglutinin on Influenza A Virus Particles: Sialyl-LacNAc Displays on DNA and PEG Scaffolds Reveal the Requirements for Bivalency Enhanced Interactions with Weak Monovalent Binders. J. Am. Chem. Soc. 139, 16389-16397.

29. Green, E. D., Adelt, G., Baenziger, J. U., Wilsonll, S., and Halbeek, H. V. (1988) The Asparaginelinked Oligosaccharides on Bovine Fetuin. J. Biol. Chem. 263, 18253-18268.

30. Suzuki, T., Horiike, G., Yamazaki, Y., Kawabe, K., Masuda, H., Miyamoto, D., Matsuda, M., Nishimura, S., Yamagata, T., Ito, T., et al. (1997) Swine influenza virus strains recognize sialylsugar chains containing the molecular species of sialic acid predominantly present in the swine tracheal epithelium. FEBS Lett. 404, 192-196.

31. Kaku, H., Kaneko, H., Minamihara, N., Iwata, K., Jordan, E. T., Rojo, M. A., Minami-Ishii, N., Minami, E., Hisajima, S., and Shibuya, N. (2007) Elderberry Bark Lectins Evolved to Recognize Neu5Aca2,6Gal/GalNAc Sequence from a Gal/GalNAc Binding Lectin Through the Substitution of Amino-Acid Residues Critical for the Binding to Sialic Acid. J. Biochem. 142, 393-401.

32. Chen, Y., Lord, M. S., Piloni, A., and Stenzel, M. H. (2015) Correlation between Molecular Weight and Branch Structure of Glycopolymers Stars and Their Binding to Lectins. Macromolecules 48, 346-357.

33. Kiessling, L. L., and Grim, J. C. (2013) Glycopolymer probes of signal transduction. Chem. Soc. Rev. 42, 4476-4491.

34. Kiran, P., Bhatia, S., Lauster, D., Aleksic, S., Fleck, C., Peric, N., Mainson, W., Liese, S., Keller, B. G., Herrmann, A., et al. (2018) Exploring Rigid and Flexible Core Trivalent Sialosides for Influenza Virus Inhibition. Chem. Eur. J. 24, 19373-19385.

35. Gestwicki, J. E., Cairo, C. W., Strong, L. E., Oetjen, K. A., and Kiessling, L. L. (2002) Influencing Receptor-Ligand Binding Mechanisms with Multivalent Ligand Architecture. J. Am. Chem. Soc. 124, 14922-14933.

36. Ferguson, C. J., Hughes, R. J., Nguyen, D., Pham, B. T. T., Gilbert, R. G., Serelis, A. K., Such, C. H., and Hawkett, B. S. (2005) Ab Initio Emulsion Polymerization by RAFT-Controlled SelfAssembly. Macromolecules 38, 2191-2204.

37. Tanaka, T., Nagai, H., Noguchi, M., Kobayashi, A., and Shoda, S.-I. (2009) One-step conversion of unprotected sugars to $\beta$-glycosyl azides using 2-chloroimidazolinium salt in aqueous solution. Chem. Commun. 3378-3379.

38. Tanaka, T., Ishitani, H., Miura, Y., Oishi, K., Takahashi, T., Suzuki, T., Shoda, S.-I., and Kimura, Y. (2014) Protecting-Group-Free Synthesis of Glycopolymers Bearing Sialyloligosaccharide and Their High Binding with the Influenza Virus. ACS Macro Lett. 3, 1074-1078.

39. Brassard, C. J., Zhang, X., Brewer, C. R., Liu, P., Clark, R. J., and Zhu, L. (2016) Cu(II)-Catalyzed 
Oxidative Formation of 5,5'-Bistriazoles. J. Org. Chem. 81, 12091-12105. 
The graphic below is used for the Table of Contents (TOC).

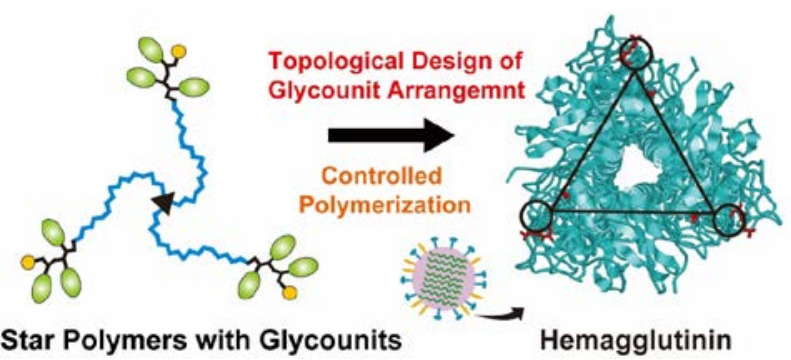

